\title{
EMERGING TECHNOLOGIES: A PARADIGM SHIFT FOR LIBRARIES IN DEVELOPING COUNTRIES
}

\author{
Stephen M. Mutula \\ University of Botswana
}

\begin{abstract}
Libraries were among early users of information technologies to manage their operations as far back as 1930s and have continued to adapt albeit slowly to changing technological environment characterized by emerging new technologies and applications and issues of globalisation. And more ever than before, libraries are facing tremendous challenges in meeting the evolving and sophisticated needs of a diversity of users. Increasingly, the global environment characterized by concerns about globalizations issues such as; digital divide, attainment of millennium development goals and the information society necessitates participation of libraries as key providers of information to partner with governments, development agencies, NGOs, academia and private sector to address these issues. Libraries are also inundated with proliferation of information resources, stiff competition from information providers, shifting goal posts of publishers, etc. Amidst these challenges, emerging new technologies and applications such as, digital libraries, e-government, e-learning, institution repositories, open source applications, biometric technologies, VSAT, VOIP, content aggregators and more provide libraries with opportunities to leverage their skills and expertise to play significant roles in addressing issues of globalization while enhancing their core business of managing and providing effective information services to meet the needs of their clientele. This paper explores how libraries are leveraging and managing emerging technologies to address the challenges of the new millennium.
\end{abstract}

\section{Résumé}

\section{Les technologies émergeantes : Un changement de paradigme dans les bibliothèques des pays en développement}

Les bibliothèques font partie des premières organisations à avoir utilisé les technologies de l'information pour gerer leurs opérations et cela depuis déjà les années 1930. Et bien que leur rythme soit lent, elles ont continué à s'adapter aux rapides mutations technologiques caractérisées par l'émergence de nouvelles technologies 
et de nouvelles applications qui ont conduit au contexte actuel marqué par la mondialisation. Aujourd'hui encore, plus qu'au paravent, les bibliothèques sont confrontées à des défis importants dans la réalisation de leur mission consistant à répondre à des besoins de plus en plus sophistiqués et en permanente évolution d'usagers tout aussi divers. De manière croissante, l'environnemnt global caractérisé par les questions liées aux problèmes de la mondialisation : la fracture numérique, l'atteinte des objectifs de développement du millénaire et la société de l'information nécessite la participation des bibliothèques en tant que principaux fournisseurs d'information en partenariat avec les gouvernements, les agences de développement, les $O N G$, le monde universitaire pour aborder ces questions. Les bibliothécaires sont aussi débordés par la prolifération des ressources informationnelles, la dure compétition entre fournisseurs d'information, Les bouleversements dans le domaine de l'édition, etc. Malgré ces défis, l'émergence des nouvelles technologies et des applications telles que les bibliothèques numériques, egouvernement, l'e-learning, les réservoirs de données institutionnelles, les applications open source, les technologies biométriques, le VSAT, Le VIOP, les aggrégateurs de contenus, etc. offrent aux bibliothèques des opportunités d'améliorer leurs compétences et leur expertise pour jouer un rôle significatif dans dans la prise en charge des questions liées à la mondialisation tout en développant leur activité principale de gestion et de fourniture de services d'information efficace répondant aux besoins de leur clientèles. Ce papier explore comment les bibliothèques utilisent et gèrent les technologies émergentes pour prendre en charge les défis du nouveau millénaire.

\section{Introduction}

Early attempts for libraries to employ some semblance of technology to transact business are recorded from the 1930s when punched card equipment was implemented for use in library circulation and acquisitions (Harter, 1997). Later in 1945, Vannevar Bush envisioned an automated system that would store information, including books, personal records and articles However, the vision of a fully computer-based library began to emerge in terminology in the mid-60s when Licklider coined the term 'library of the future'. Since then major developments in the use of ICT in libraries started and have continued unabated to-date.

During the 1960s, major development of information technology applications included disk and tape storage devices giving computers the speed, storage and ability needed for on-line interactive processing and telecommunications, production of the keyword in context or KWIC index for articles appearing in Chemical Abstracts, LC MARC making it possible for libraries to exchange and share bibliographic data 
as well as undertake migration of data between systems, establishment of Ohio Computer Library Centre (OCLC) which today is estimated to have over 40 million works and essentially serves as a catalog of every book and recorded work to the Western world, and establishment of Advanced Research Project Network (ARPANET) the predecessor of the Internet within university environments in the US. (Australian Advisory Council on Bibliographical Services, 1967).

Similarly, major strides in the use of technologies in libraries during the 1970s included librarians working closely with IT units and using programming skill of IT departments to develop library based applications. Software developers entered into partnership with minicomputer hardware manufacturers to offer a complete 'package solution' - the 'turnkey system. The 1970s also witnessed the use of commercial systems for searching reference databases such as DIALOG. Similarly, automated library cooperatives, stand alone single user circulation systems, and Online Public Access Catalogues emerged (Brown, 1967).

The 1980s on the other hand was a period of gradual transition from in-house built systems to integrated library management systems created by third party vendors. These systems included among others ADLIB, GEAC, VTLS, URICA, Dynix, etc. Similarly, high capacity storage media such as WORMS, and CDROM emerged. The arrival of CD-ROM provided access to overseas databases at faster, cheaper and more reliable pace. Common databases included cataloguing databases such as MARC; UMI's Business Periodicals on Disk and Elsevier's ADONIS (CAVAL Limited, 1987; Boyd, 1971).

Since the 1990s to date libraries have witnessed the growth of the internet and the evolution of digital libraries. These developments have been accompanied by the move from mediated to un-mediated access to information. Vendors have increasingly mounted their databases and other information resources on servers under their direct control and provided access to them via the internet as a result of universal availability of cheap and powerful PC workstations, the greatly improved telecommunications and huge reduction in the cost of mass storage. Similarly, journal publications have emerged on the Internet. In addition, databases that were previously available on-line became available on CD-ROM, either in parts or in their entirety. Other developments include but are not limited to: the growth of the internet in terms of speed, bandwidths, content, convergence, number of devices and applications supported (Nelson, 2001).

Moreover, content providers have emerged and are trying to publish content on their own domains and build off their brand. Similarly, content aggregators using RSS (Rich Site Summary) feeds and various other technologies are offering persistent search - a means to access any information about a specific topic as it becomes available. Likewise, Search engines now offer various services to lock users into their sites. These services include among others: free email, news search, blogging 
platform, content hosting, office software, calendars, etc (Search Marketing, 2006). New technologies and applications that promise great potential for libraries continue to emerge. They include for example, VOIP, biometric systems, e-government, e-learning, Wikis, etc

\section{Globalisation imperatives: Implications for libraries}

The world has indeed become a global village as predicted decades ago. Concerns about digital divide, the move towards attainment of information society, and Millennium Development Goals (MDGs) and, e-government are demands of global dimension that libraries with the help of modern technologies can assist to address. Governments the world over are now preoccupied with among other things how to bridge the digital divide in their midst, attain and information society status and meet the Millennium Development Goals (MDGs) targets by the year 2015. The digital divide, perceived as gap that exist in terms of technology access and use between and among countries is now coming of age. The MDGs initiative on the other hand is a UN global programme that was mooted at the dawn of the $21^{\text {st }}$ century aimed at eradication of extreme poverty and hunger, achievement of universal primary education; promotion of gender equality and empowerment of women; reduction of child mortality; improvement of maternal health; combating HIV/AIDs, malaria and other diseases; ensuring environmental sustainability; and development of global partnerships for development for the attainment of a more peaceful, just and prosperous world by all countries.

Bridging the digital divide, attainment of information society and the MDGs are by and large predicated on inclusive, effective access and use ICTs by the populace. Integrating ICTs in the lives of the people requires attainment universal access and universal service. The term universal access has generally come to be associated with enabling every person to have access to necessary ICTs including the internet within a given distance (usually 5 kilometers of walking distance) for enhanced communication. Similarly, the concept of universal access basically means that the ICT should be used by all people irrespective of their physical (dis)abilities. Universal access and universal service are now at the centre for bridging the digital divide especially in developed countries. Achieving universal access and service strategies are increasingly perceived as ways that can assist in bridging the digital divide to enable countries achieve information society needed for meeting the millennium development goals.

The importance of access to information communication technologies to enhance access to information is now well established. The World Summit on Information Society (WSIS, 2003) in Geneva in 2003 noted that digital revolution fired by the 
engines of the information and communication technologies had fundamentally changed the way that people think, behave, communicate, work and earn their livelihood, new ways of creating knowledge, educating people and disseminating information, conducting economic and business practices, running government, engaging politically, providing speedy delivery of humanitarian aid and healthcare, and improving the living standards for millions of people around the world among others. The WSIS recognised that the information society that was to be built was one which is inclusive, where all persons without distinction of any kind were empowered freely to create, receive, share and utilize information and knowledge in any media and regardless of frontiers (WSIS, 2003).

Libraries are key partners alongside governments, development agencies, NGOs, research institutions and academia in driving the globalization. It is in this context that IFLA made submission to the World Summit on Information Society (WSIS) calling on world leaders to recognise that libraries had a key role in tackling the growing digital divide. IFLA impressed on the world leaders to concentrate investment in the existing library network and avoid reinventing the wheel. IFLA in its submission underlined the following information readiness issues as pre-conditions for participating in an information society. (Commonwealth Telecommunications Organisation, 2004):

- Providing affordable or free-of-charge access for their citizens to the Internet.

- Specific training programmes in the use of ICTs.

- National policies and laws to enhance content creation.

- Appropriate, authentic, and timely content in languages the people understand.

- Commitment of member states to connect all their public libraries to the Internet by 2006.

- Support for skills development of librarians.

- Ensure that intellectual property laws for electronic publications do not prevent public access.

- Public investment in information and telecommunication technologies.

- Enable public libraries providing public access to be eligible for affordable connection charges.

IFLA noted that people who cannot afford the hardware and software, together with the telecommunications charges will need access to expensive electronic publications that can be afforded only on a collective basis. IFLA argued that the library is the key agency in providing an answer to this problem. The library has the additional advantage that it can also provide an environment where the necessary searching and interpretative skills can be acquired and developed. (Commonwealth Telecommunications Organisation, 2004). The emerging new role of libraries in the global environment to meet the needs of society of the $21^{\text {st }}$ century and beyond can 
therefore be over emphasised. In this role and effective management of ICT is critical.

\section{Emerging technologies and applications for libraries}

There are several emerging technologies and applications for libraries that require new thinking on the part of library managers. These technologies and applications include but are not limited to digital libraries, e-learning, e-government, content aggregators, VOIP, open source software, etc.

Digital libraries: The Digital Library Federation (2004) defines digital libraries broadly as, organizations that provide the resources, including the specialized staff, to select, structure, offer intellectual access to, interpret, distribute, preserve the integrity of, and ensure the persistence over time of collections of digital works so that they are readily and economically available for use by a defined community or set of communities. Brown (2004) citing Atkins notes that concept of digital library has been applied to a wide variety of offerings from collections of electronic journals to software agents that support inquiry-based education to collections of email to electronic versions of a public library, to personal information collections, and even to the entire Internet. Digital libraries have the potential to make information more available, raise its quality, and increase its diversity. Moreover, digital libraries can:

- Offer great user satisfaction,

- Offer several ways in which libraries can improve services while reducing cost,

- Provide instantaneous access to online information,

- Offer all time every where access to information so long as requisite infrastructure is in place,

- Obviates deterioration over time associated with physical media.

The design and implementation of digital libraries require a robust and elaborate infrastructure involving PCs/servers, web authoring languages, browsers, different applications programmes, internet connectivity, content, information architecture, standards, etc. The World Wide Web provides the platform for creating and providing access to digital library collections for large group of users. On the other hand, networks such as the Internet and intranets enable digital libraries to be accessed rather than users having to physically visit the library to consult electronic documents.

In developing digital libraries, content need to be collated and organized. One way of generating content for digital libraries is through digitisation. Through this process, old materials in paper format are converted online while others are directly 
generated as electronic documents such as word processed documents, e-mails, information by-products and end-products, image files. On the other hand, the information architecture consists largely of websites and associated hyperlinks. The information architecture should be designed taking care to develop suitable userinteraction features so that the digital library can be used effectively. The design and implementation of digital libraries demand enhanced user interfaces that support interaction between users and information. (Mitchell, 1999).

E-government: E-government is the use of information and communication technologies (ICTs) to improve the activities of public sector organizations (Heeks, 2002). Because government services are expected to reach every citizen, e-government supporting infrastructure tends to be expansive. Libraries can exploit such infrastructure to offer information services to a large number of people. For example, Durban Metropolitan Municipal Council in South Africa, made attempts to initiate the Community Information Link (CIL) project in 2000 by using an existing public library network reaching 40 public libraries, to provide Web-based community and council information via a client/server network with touch screens and a browser. Though the project is said to have failed, it demonstrates just how libraries can evolve to take advantage of new technologies (Anonymous, 2002). Similarly, in Australia, the Victorian government through e-government initiative aims at complementing the delivery of online government services with strategies to encourage use of these services, particularly for people who find it difficult to access the Internet due to their level of income, physical ability or geographic location. The government in Australia has through this initiative established the Virtual Library that provides online access to library resources 24 hours a day, 7 days a week (Egovernment Resource Centre, 2002).

E-learning: E-learning is the appropriate use of information and communication technologies in teaching and learning towards student-oriented, active, open and life-long learning. E-learning can be conducted in various modes, including face-toface interactions, paper, text books and information and communication technologies (University of Botswana, 2001). The world over, institutions of higher learning especially universities are increasingly implementing various forms of elearning to enhance classroom teaching and at the same time improve the quality of research. The emergence of the Internet in the 1990s and the development of networked environments encompassing a range of computer, multimedia and communication technologies have resulted in much greater focus on interactive and connected learning experiences for students (Department of Education and Youth Affairs, 2001). E-learning technologies provide the opportunity to enhance participatory teaching and learning from anywhere any time; facilitate joint group work; provide the opportunity for reduced costs; encourage self-directed learning and enable students to maintain electronic portfolios of their work. An electronic portfolio 
posted on the Web, can allow viewing and sharing in the works of other people (Livingstone, 2004).

The growing adoption of e-learning strategies especially in higher education requires libraries to transform in order to serve the increasing online populace. Systems developers and librarians should provide systems that support e-learning including content. Libraries can support e-learning by putting in place relevant information infrastructure. Such infrastructure would include e-resources, databases, digital libraries, OPACs, etc. Moreover, the modern library can facilitate e-learning by ensuring that students learn at their own pace; enhancing customised individual learning preferences, enabling students to explore learning materials with more senses (multiple modes and multi-media); providing an easy means of finding, handling, and publishing electronic materials, enhancing access to relevant national and international resources, supporting collaborative research, sharing knowledge and resources, enhancing online information literacy in order to provide students with a complete set of skills and information on how computers are used for information storage and retrieval.

Open source software: Open source has entered the mainstream software market and its impact is becoming apparent especially in the software industry and in society as a whole. Open software is a useful tool to allow developing countries to leapfrog into the information age. The major benefits of open software and open standards include: reduced costs and less dependency on imported technology and skills; affordable software for individuals, enterprise and government; universal access through mass software rollout without costly licensing implications; access to government data without barrier of proprietary software and data formats; ability to customise the software to local languages and cultures and facilitate participation in global network of software development. Open source software, gives librarians the opportunity to venture into application development in partnership with counterparts and other professionals around the world. Open source provides developing countries the opportunity to automate their services.

VOIP: Voice over Internet Protocol (VOIP) has emerged as a cheaper means of telephone communication compared to the fixed line telephony. Through Internet telephone, it is possible for libraries to engage with their customers and suppliers by routing voice traffic over organization network. The VOIP is made possible because of convergence of data networks and telephone services. Libraries should position themselves and also find innovative ways through which they can exploit VOIP technology to enhance the provision of library and information services.

Content aggregators: Content aggregators can be perceived from two angles. On one hand, they are individuals or organizations that gather Web content and / or applications from different online sources for reuse or resale. From this perspective, there are two kinds of content aggregators; those who simply gather material from 
various sources for their Web sites, and those who gather and distribute content to suit their customer's needs (TechTarget, 2007). The content aggregators combine information such as news, sports scores, weather forecasts and reference materials from various sources and make them available to its customers (Search Marketing, 2006). The other angle of perceiving content aggregators is from the point view of programs known as feed readers that check a list of feeds on behalf of a user and display any updated articles that they find.

VSAT (Very Small Aperture Terminals): VSAT is a satellite communication system that serves usually home and business users. A VSAT end user uses a box that interfaces with the user's computer and an outside antenna with a transceiver. The transceiver receives or sends a signal to a satellite transponder in the sky. Each end user is interconnected with the hub station via the satellite. VSAT devices are cheaper and easier to set up than conventional satellite communication technologies and can bring phone and internet links to remote areas. VSAT technology can be used by libraries that are remotely situated from urban centres for Internet connectivity. VSAT as a means to connect to the Internet is gaining popularity because of the ease with which it can be installed.

Videoconferencing technologies: Videoconferencing refers to communication technology that uses high speed telecoms links which allow people to hold virtual meetings across the globe. This communication system allows audio/video to be transmitted in real time. Moreover, two-way conversations are possible. Videoconferencing requires deployment of a videoconferencing system to hook up with other people elsewhere so as to eliminate travel costs. Libraries could with increasing modernization of telecommunication infrastructure use this mode of conferencing to communicate, collaborate and share information (Video Conferencing Glossary, 2007).

Biometrics: Biometrics is the biological identification of a person using retinal patterns, hand geometry and voice. Biometric has been integrated into hand-swipe clocking system as a workforce management solution that works to prevent employees clocking for each other, calculates employees' attendance time on hourly, daily or even weekly basis automatically. The system positively identifies each employee when clocking, by scanning the unique size and shape of their hand. Once clocked in, information is sent through to the PC software for automatic calculation, editing and analysis. This data allows one to stay in complete control of the employees' time and attendance at all times. The system enables the employer to determine: clocking times, hours worked, overtime, lateness, absence, holidays/leave planner, sickness, and fire roll call and much more. The biometric clocking systems can be applied in libraries for employee working patterns management.

Blogging: Blogs are personal journals made up of chronological entries (Huffaker, 2004). They also provide the means by which people give comments or feed- 
back to each posting on the blog. Blogs can be used in libraries to enhance learning environments especially in classroom settings because they promote literacy through storytelling, allow collaborative learning, and provide anytime - anywhere access. They provide an open information sharing approach and serve as forums for announcements, and sources of news.

Wikis: A wiki refers to a script driven website that provides real time conversations and permits contributors to build knowledge management applications. Wikis are people centred, improve and extent networks, enhance learning environment, provide environment for unique content creation and are relatively cheap because they are based on open source software. These tools are suitable for knowledge creation, discovery and promoting lifelong learning. They can be deployed in libraries to enhance learning, sharing of information, collaboration and communication.

Telecentres: The concept of telecentre in its generic form refers to a shared facility that provides public access to information and communication technologies (Roman, 2003). The purpose of telecentres is to provide a range of services responding to the needs of a community by sharing adequate facilities and assistance. The offered services are largely based on ICT by sharing local equipment and connectivity to telecommunications networks. These services include but are not limited to: access to Internet, e-mail, file transfer, electronic libraries, databases, government and community information systems, market and price information (Community Telecentres Association, 2000). Telecentres have become important ICT infrastructure especially in developing countries for providing wider Internet access.

Institutional repositories: Refers to a set of services, organization, access, distribution and long-term preservation of digital resources. Often, institutional repositories contain web pages, books, conference papers, datasets, maps, technical reports, etc. Institutional repositories have several advantages such as centralized archive of research, increased visibility, immediate access to full text, long term archiving and preservation, collaboration between departments within the organization, convenient and easy access to materials. Institutional repositories are gaining popularity especially in universities and offer alternative ways of providing information from those resources that have often not found their way easily in libraries. Libraries often are being called upon to set up such repositories with the help of research coordinating units and IT departments for infrastructure support. In southern Africa, the University of Pretoria and University of Western Cape (both in south Africa) and the University of Botswana are among other universities that have set up such repositories.

Electronic journals and online databases: These are journals that are available electronically and may be subscribed to. Increasingly, it is possible to get the full text of an electronic journal as it is possible with the EBSCOHOST database. SimIlarly, online databases are information transferred to hard discs or magnetic tape or 
their equivalents and read by being mounted on the computer. Online databases store information at the search tool's website. It is fairly easy to add material to an online database. Examples of online databases include ERIC, Web of science, EBSCO, CINAHL and LISA. Libraries with the relevant infrastructure and necessary funding are able to provide their users with access to wide range of such resources.

\section{Libraries' readiness for the information age}

Libraries are increasingly being inundated with many technological innovations. However, there are not yet established methods or tools from mainstream information science discipline to assist in measuring the preparedness of such libraries to deploy and apply such emerging technologies. Nevertheless models from development, business and government may be helpful. For example, e-readiness models that are used to evaluate the breadth and depth of the digital divide between more and less developed countries could come in handy for libraries. Several e-readiness tools developed in academia, private sector and development agencies are available. These tools collectively consider e-readiness of an organization, country or community with respect to (IRMT, 2004; Economist Intelligence Unit, 2006):

- physical infrastructure (high bandwidth, reliability, and affordable prices)

- Integration of current ICTs throughout businesses

- ICT-driven applications and services,

- Extensive usage of computers,

- Skilled workforces,

- Guidelines and good practices for computer systems security,

- Backup and business continuity planning,

- Documentation standards and system engineering procedures for ICT,

- ICT systems and formal requirements management process,

- Standards formats for storage and retrieval of data,

- Information management policy,

- Policy on how information should be organized,

- ICT strategy,

- Provision of ICT awareness to new staff.

For libraries to meet the challenges of globalization using emerging technologies, they need to achieve a reasonable level of readiness with respect to ICT integration in their operations. The concerns about existence of digital divide and the possibility of excluding those affected from mainstream benefits of ICTs has occasioned several global, regional and national initiatives aimed at bridging the digital divide. The readiness of libraries with respect to their ability to deploy and apply 
emerging technologies can enable them to partner with government, development agencies, international bodies, etc in the endeavour to address globalization issues.

The Digital Opportunity Task Force (DOT FORCE), the outcome of G8 summit in Okinawa Japan in 2001 was concerned with addressing the digital divide. DOT FORCE succeeded in bringing awareness about the need to do something about the digital divide (DOT FORCE, 2001). It suggested a number of initiatives such as a French Government project (ADEN) to create a network of Internet community access points in Africa; the project to implement Edu-Telecenters in Malawi, Kenya, Uganda, and Zambia, etc. The DOT FORCE set up an agenda that was picked up by others, for example, the WSIS meetings. In Africa, the New Partnership for Africa's Development (NEPAD) has one of its objectives, the development of local content in its attempt to help bridge the digital divide on the African continent (NEPAD, 2002). Likewise, the African information society initiative on the other hand, envisages by the year 2010 to attain a sustainable information society in Africa. In such society, information and decision support systems would be used to support decision making in all the major sectors of the economy in line with each country's national development priorities. The attainment of AISI aspirations would be a big step in assisting to bridge the digital divide (UNECA. 1999).

Libraries may contribute significantly to bridging the digital divide by applying non conventional approaches to bridge the divide because of Africa's peculiarities. For example though traditional broadcasting media have maintained a larger coverage than telecom and Internet, and are in many cases a cost-effective and more appropriate medium for simple information dissemination, they have remained commercialised and consequently limiting their reach. Such commercial media tends to reach only those who are privileged in society. There is need to enhance access to media through local languages newspapers, and community radios that can address the unique needs of local communities such as rainfall patterns, food security, cultural practices, politics, government projects, health, education, church functions, weddings, etc. There are attempts in the region to introduce community radios in such places as Mozambique, South Africa, Kenya, to mention but a few. Other countries such as Botswana are yet to agree on the way forward as far as community radios are concerned.

The diversity of African people and the expansive land mass may require the use of outdoor advertising using road-shows, billboards, promotion posters, advertisement around strategic places such as shops, churches, schools, stadia, airports, clubs, and public transports where there is large catchments of the public (Kapange, 2006). Such approaches may draw the attention of the public to availability of information resources in our libraries. The outdoor industry has successfully helped to entrench mobile phone connectivity in rural areas in Africa. Etta \& Wamahiu (2003) wonder how much use libraries have made of telecentres, open source soft- 
ware to develop local applications etc. The use of low cost technologies such as radio that is pervasive in Africa can enhance access to information (Hyder, 2005). In Kenya, the use of VSAT to enhance connectivity in rural areas has helped to provide internet connectivity especially in outpost schools, government centres in such places.

In some villages in India such as the region of new India, cyber cafes make use of state of the art solar cells and a wireless connection to the Internet. Each village has a room equipped with computers serving as knowledge centres. The knowledge centres have been set up through funding from non-profit organizations. The centres provide information that is largely of local content nature that include market prices for crops, job listings, details of government welfare schemes and health advise (The Economist Newspaper and The Economist Group, 2005).

Largely libraries in general do not seem to be prepared to transform timeously to cope with the rapid demands of globalization. This is demonstrated by their minimal or none participation in global initiatives such as DOT FORCE, MDGs, information society, NEPAD and AISI. In the absence discernible involvement in global initiatives that are driving globalizations, libraries will not effectively position themselves to play their rightful role in the information age.

\section{Factors affecting integration of technologies in libraries in developing countries}

The revolutions in technology and global imperatives have impacted on the library profession in a number of ways. For example, there are now several information providers, such as ISPs and the media. Similarly, new technologies being used in library are exerting pressure on the library to:

- provide hardware and software support in the library, as well as for remote users.

- provide search ability to retrieve Internet resources, such as full-text databases, e-journals, etc.

- create a user-friendly OPAC display for Internet resources.

The need to convert the manual files, including parts of the library catalogue are part of the challenges facing modern libraries, yet absence of standard record formats (Boyd, 1971) are not making matters any easier. A number of standards are available though still undergoing various revisions such as Dublin Core, Warwick Framework, TEI, etc. Moreover, the cost and complexity of data conversion was a major impediment to early library systems development. Libraries' reliance on parent organisation's computing facility places additional demand on computing power 
as libraries grew in stock and expanded. In situations where applications are competing for computer time, data processing managers rate the requirements of the library below those of other functional areas of the organisation.

Marshall (2005) points out that though most library systems have greatly evolved to provide enhanced functionalities especially with respect to providing print materials; there is less sophistication for features to manage electronic content. Often librarians are required to buy add-ons for back-end management functions and front-end delivery systems for their electronic collections. The increasing acquisition of electronic content in libraries has therefore not kept pace with systems development.

Marshall (2005) is of the view that several players in library market place create problems rather than opportunities. From the business perspective, this may not augur well for profitability, standardisation and sophistication of the system, though this gives the libraries choice from what to select. On the other hand, though the acceptance of digital libraries is rising, there are several challenges of economic, social, legal, organizational and technical nature that need to be addressed. For example, digitisation is an expensive and, labour-intensive process largely because of the huge volumes of materials to digitise. Similarly, the long term costs of digital preservation are unknown, though studies and experts indicate that these are likely to be significant. Moreover, legal questions that revolve around copyright will have to be addressed. To digitise is to make a copy.

Though the Internet remains undisputed as the most comprehensive source of information, there are a number of issues that need to be addressed. For instance anybody can publish on the Net without restrictions or the publication being peer reviewed. Similarly the information on the Net is growing at phenomenal rate without adequate tools for bibliographic control, searching, filtering and retrieval. The search engines are inadequate tools as they do not review the documents, directories and gateways only cover, limited materials. In addition, some materials are hidden behind firewalls and remain inaccessible.

As digital libraries become part of the traditional library infrastructure, the major challenge remains technological obsolescence of the devices to read them. Likewise, the major worry is the funding for the regular refreshing. Digital preservation is an ongoing operation, requiring a regular future expense. Within organisations, the design and implementation of digital libraries require commitment of sufficient resources. Similarly, adequate and regularly available skills are needed to ensure that the content is properly collated, organised and then digitised. There is also need to work with publishers, authors or holders of other copyrighted material to ensure observance of legal issues involved in digitisation. On the other hand, issues of technical nature involve appropriate selection and use of tools for digitisation especially with regard to indexing of texts of non-English language. The choice of tools 
should take cognisance of the needs of users with regard to ease of finding materials (Stueart, 2006).

Digital libraries in general are yet to be rooted and institutionalized in people's cultural life. They pose challenges of use-ability nature. Despite the fact that many users are gaining high-level of familiarity with computer and web searching, they are still unable to see the value of digital libraries due to their poor design especially with respect to navigation support and usability. Users generally perceive usability as poor and one that obligates them to keep up with training and retraining. It is important that activities of digital libraries should inform interface design taking into account people's cognitive abilities. By and large, digital libraries provide simple searching support, and on the whole lack integrated support for information gathering and organization. Poor system design in principle provides information that is available, but which in practice is inaccessible (Adams, Blandford, and Lunt, 2005). In addition, digital library should be designed to allow all users with varying abilities to feel able to utilize the resources. Digital libraries in their current form require the intervention of intermediaries to make them more effective and usable.

\section{Conclusion and the way forward}

Faced with challenges that have been occasioned by revolution in technology and globalisation, libraries should strive to become developers and suppliers of automation systems. There is need for libraries to explore once again the consortium arrangement of 1980s as an avenue of quick library automation. Consortium approach may assist libraries to share costs of hardware, software and personnel. Requisite technology now exist that can allow several libraries to bundle together their bibliographic data and share applications. The increasing availability of e-resources makes this imperative. This model of library automation may enhance standardisation of systems, data formats, etc. However, issues of management and interorganisational priorities must be addressed.

Library schools should review their library automation courses to include core software and hardware components such as applications development, programming, network administration, web design, content development, etc. The libraries of $21^{\text {st }}$ century should not be completely reliant on IT department for systems support. Though libraries need to cooperate with IT departments in a number of areas they should not be dependent upon them entirely. On the other hand, there is the thinking that if library systems were part of enterprise wide information management systems they would attract attention in terms of resources and opportunity to develop their own IT skills. However, current practices of enterprise resource planning tend to give the responsibility of IT management to information systems de- 
partment. Such set up is already complex and would not give much attention to the needs of library information management.

There is increasing availability of open source that may encourage library staff to get involved in their own application development. The openness of the source code and collaborative nature of OS software development allows local talent to cooperate within the globally distributed teams of specialists and modify and adapt software for local needs. If properly adopted, the OS software can stimulate the growth of an indigenous software industry. Similarly, with increased use of ICT in society in general it becomes imperative that libraries and information centres should play the role of imparting information literacy competencies in order to exploit information resources that the electronic age engenders.

The scale of the economic challenge for digitisation requires cooperation at institutional, country and regional level. More public private partnerships are needed to digitise and exploit the resources in our libraries. In addition, close collaboration with publishers and other rights' holders is necessary to find new models for bringing copyrighted material online. Furthermore, investments in digitisation must be accompanied by organisational changes within the institutions concerned. New types of skills are necessary to deal with the technological tools, together with the extensive expertise that already exists within the institutions. For libraries, this means tackling training and re-skilling as well as recruiting staff with the new skillsets.

\section{References}

Adams, A., Blandford, A., and Lunt, P. (2005). Social empowerment and exclusion: A case study on digital libraries. [Online]. Available at: http://www.uclic.ucl.ac. uk/annb/aaabplToCHIpreprint.pdf [Accessed 2 July 2005].

Anonymous. (2002). E-government for development success/failure case study No.11: Durban Council's Community Information Link. [Online]. Available at: http://www.e-devexchange.org/eGov/durbancil.htm [Accessed 4 August 2003]

Atkins, T. (2005). Digital divide narrowing fast, World Bank says [News item 13:52)]. 24 February 2005.

Australian Advisory Council on Bibliographical Services. (1997). Current projects in library automation: an Australian directory. Canberra, AACOBS.

Boyd, R.W. (1971). 'The new technology and education for librarianship'. Australian Library Journal 20: pp. 12-15, June 1971. 
Brown, W. L. (1967). A computer-controlled charging system at Essendon Public Library'. Australian Library Journal 16: pp. 231-238, December 1967.

Brown, M.E. (2004). History and definition of digital libraries. [Online]. Available at: http://www.southernct.edu/ brownm/dl_history.html [Accessed 22 July 2007].

Bush, V. (1945). As we may think. Atlantic Monthly. 176(1), 101-8.

CAVAL Limited. (1987). The COOL-CAT Trial report. Melbourne. CAVAL

Commonwealth Telecommunications Organisation. (2004). Regional roundup: Libraries help bridge the digital divide': IFLA submission to WSIS process. [Online]. Available at: $\quad$ http://www.ictdevagenda.org/frame.php?dir=07\&sd=

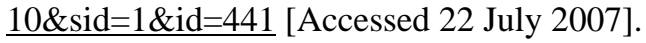

Community Telecentres Association. (2000). Definitions and types of community telecentres. [Online]. Available at: http://perso.orange.fr/christian.carrier/ definition.htm [Accessed 4 January 2007].

Department of Education and Youth Affairs. (2001). Information and communication technology for teaching and learning. [Online]. Available at: http:// www.detya.gov.au/schools/publications/index.htm [Accessed 5 September 2004].

Digital Library Federation. (2004). A working definition of digital library. [Online]. Available at: http://www.diglib.org/about/dldefinition.htm [Accessed 22 July 2007].

DOT Force. (2001). Digital opportunities for all: Meeting the challenge. Report of the digital opportunity task force including the Genoa plan of action. [Online]. Available at: http://www.dotforce.org/reports/DOT Force Report V 5.0h.html [Accessed 22 April 2004].

Economist Intelligence Unit. (2006). Digital divide narrows. London. The economist. [Online]. Available at: http://www.ibm.com/news/be/en/ 2006/04/2601.html/ [Accessed 18 February 2007].

The Economist Newspaper and the Economist Group. (2005). Behind the digital divide. [Online]. Available at: http://www.economist.com/printedition/Printer Friendly.cfm?Story_ID=3714058 [Accessed 10 April 2007].

Egovernment Resource Centre. (2002). Government online: Overcoming inequalities of user access - the digital divide [Online]. Available at: http:// 
www.egov.vic.gov.au/Victoria/StrategiesPoliciesandReports/Reports/ReportCard/ digitaldiv.htm [Accessed 4 August, 2003]

Etta, E. and Wamahiu, P.S. (2003). Information and communication technologies for development in Africa: The experiences with community telecentres. Ottawa. IDRC.

Harter, S. (1997). Scholarly communication and the digital library: Problems and issues. Journal of Digital Information. 1(1). [Online]. Available at: http://jodi. ecs.soton.ac.uk [Accessed 22 July 2007].

Heeks, R. (2002). E-government and development, News Link. [Online]. Available at: http://idpm.man.ac.uk/newslink02.htm [Accessed 1 July 2003].

Huffaker, D. (2004). Educated blogger: Using weblogs to promote literacy in classroom. [Online]. Available at: http://www.firstmonday.org/issues/issue9 6/ huffaker/index.html [Accessed 26 September 2006].

Hyder, S. (2005). The information society measurements biased by capitalism and its intent to control dependent societies: A critical perspective. The International Information and Library Review 37, 25-27.

IRMT. (2004). The e-records readiness tool. London. Author

Kapange, B. (2006). Globalizing agricultural information: Improving access to remote areas in Tanzania. Paper prepared for First IAALD Africa Chapter Conference held at the Hotel Intercontinental Nairobi from 21-26 May 2006 Nairobi, Kenya

Livingston, P. (2004). Laptops unleashed: A middle school experience. Learning and Leading with Technology, 31(7), 12-15.

Marshall, B. (2005). Looking toward the future of library technology. Computers in Libraries. 25 (25), 39-42

Mitchell, S. (1999). Interface design considerations in libraries. In D. Stern (Ed.). Digita libraries: philosophies, technical design considerations, and example scenarios (pp. 131-181) New York: The Haworth Press, Inc.

Nelson, M.R. (2001). Technologies and policies for bridging the digital divide, paper presented at seminar held at Grand Palm Hotel on 6 April 2001, 1-4. 
Nepad. (2002). NEPAD. [Online]. Available at: http://www.nepad.org/ [Accessed 5 May 2003]

Roman, R. (2003). Diffusion of innovations as a theoretical framework for telecenters. ITD, 1 (2), 53-66

Search Marketing. (2006). History of search engines: From 1945 to Google 2006. [Online]. Available at: http://www.search-marketing.info/search-engine-history/ [Accessed 13 October 2006].

Stueart, R. (2006). Digital libraries: The future of scholarly communication. Paper presented at The University of Botswana in UB Library Auditorium. From 10-1 $1^{\text {th }}$ August 2006.

TechTarget, (2007). Content aggregator. [Online]. Available at: http:// searchwebservices.techtarget.com/sDefinition/0, sid26_gci815047,00.html [Accessed 4 January 2007].

UNECA. (1999). Africa's information and communication infrastructure, IECA/CM.22.5. Addis Ababa. Economic Commission for Africa, 6-8 May

University of Botswana. (2001). University of Botswana eLearning (unpublished paper).

Video Conferencing Glossary. (2007). Emerging technologies. [Online]. Available at: http://www.uen.org/delivery/ivc_glossary.shtml [Accessed 12 January 2007].

WSIS. (2003). World summit on the information society: Draft declaration of principles. Geneva: [Online]. Available at: http://www.wsis-pct-org/prepcom2declaration.html [Accessed on 7 November 2004]. 